\title{
WEB DEVELOPER INFORMASI BERBASIS ALGORITMA PEMROGRAMAN
}

\author{
Galih Mahalisa, M. Kom \\ Fakultas Teknologi Informasi, Universitas Islam Kalimantan Muhammad Arsyad Al Banjari Banjarmasin \\ Email : galih.mahalisa@gmail.com
}

\begin{abstract}
ABSTRAK
Bidang informatika / komputer pada tingkat SMA bukan sebagai mata pelajaran wajib tapi hanya kegiatan ekstrakurikuler, jadi memang tidak ada tenaga pengajar khusus yang ahli di bidang ilmu komputer yang ditunjuk sebagai pelatih siswa - siswi yang akan dikirimkan mengikuti lomba Olimpiade Sains Nasional. Kebanyakan siswa tersebut belajar secara otodidak, pihak sekolah hanya bisa memberikan fasilitas perangkat yang diperlukan, tapi tidak menyediakan tenaga ahli (guru) yang ahli di bidangnya. Web developer informasi bisa dikatakan sistem informasi dengan platform web yang diperuntukan untuk referensi materi logika matematika dengan tujuan untuk belajar algoritma pemrograman dan merupakan bidang keilmuan dari perlombaan Olimpiade Sains Nasional (OSN) yaitu informatika / komputer. Sistem informasi tersebut digunakan untuk pendampingan dalam pembelajaran Informatika yang berisikan bank soal sebagai referensi belajar algoritma pemrograman dan disertai soal quiz sebagai latihan. Kesimpulan yang didapatkan setelah melakukan implementasi dan beberapa pengujian, maka dapat dipaparkan yaitu: Tahap pengujian usability hasil analisa pengujian maka diperoleh presentase $81 \%$. Dari skor tersebut untuk aplikasi yang sederhana termasuk dalam kategori baik.
\end{abstract}

Kata Kunci : OSN, Web, Informatika, Komputer, Soal

\section{PENDAHULUAN}

Salah satu program pembinaan pendidikan dari Direktorat Pembinaan SMA melalui kegiatan Olimpiade Sains Nasional (OSN) ada bidang keilmuan yang ditawarkan, salh satunya informatika / komputer. Setiap tahun sekolah akanmengirimkan siswa/siswi terbaik untuk mengikuti perlombaan OSN sejak tingkat sekolah sampai tingkat internasional, dengan tujuan bisa membanggakan pihak sekolah ataupun institusi terkait dengan bidang keahlian masing-masing khususnya dalam hal ini bidang informatika / komputer.

Bidang informatika / komputer pada sekolah SMA bukan sebagai mata pelajaran wajib tapi hanya kegiatan ekstrakurikuler, jadi memang tidak ada pengajar atau pendamping khusus untuk melatih siswa dalam belajar informatika / komputer. Kebanyakan siswa belajar secara otodidak. Pihak sekolah hanya bisa memberikan fasilitas komputer beserta jaringan internet untuk praktek secara mandiri dan didampingi mentor guru, walaupun bukan basic informatika.

Web Developer Informasi bisa dikatakan sistem informasi dengan platform web yang diperuntukan untuk referensi materi logika matematika dengan tujuan untuk belajar algoritma pemrograman yang merupakan bidang keilmuan dari informatika / komputer.

Sistem tersebut digunakan untuk pendampingan dalam pembelajaran informatika / komputer yang berisikan materi dari berbagai referensi dan disertai soal quiz sebagai latihan.

\section{METODE PENELITIAN}

Desain penelitian yang dipakai adalah Studi Kasus yang merupakan penelitian yang memusatkan perhatian pada suatu kasus tertentu dengan menggunakan individu atau kelompok sebagai bahan studinya. Dalam hal ini kasus ini difokuskan untuk menganalisa pola pengujung 
dan mengumpulkan hasil observasi yang lebih dalam terhadap pengunjung.

Berdasarkan hasil observasi dari studi kasus yang didapatkan, maka penelitian ini menggunakan pendekatan penelitian dan pengembangan ( Research and Development) adalah metode yang digunakan untuk menghasilkan produk tertentu dan menguji daripada keefektifan produk tersebut bagi pengguna.

Langkah-langkah yang ditempuh dalam menyelesaikan penelitian sebagai berikut:

1. Studi literatur

2. Analisis sistem

3. Perancangan dan implementasi sistem

4. Pengujian

5. Penyusunan laporan

\section{HASIL DAN PEMBAHASAN}

a. Tahap Perancangan

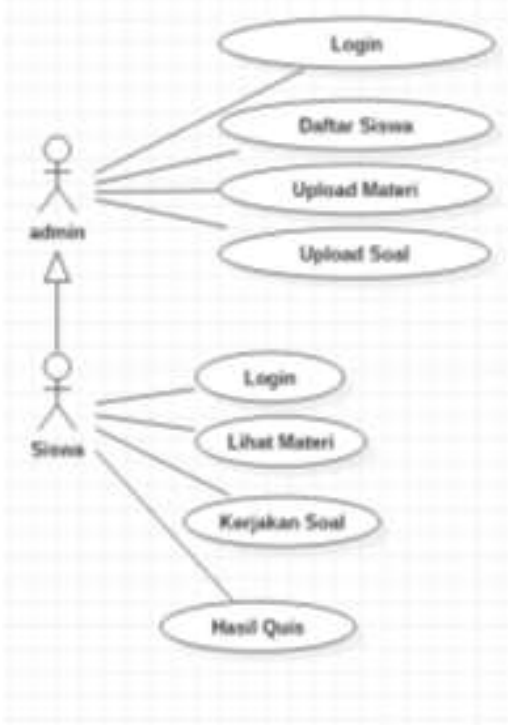

Gambar 1 Usecase

Pada tahap perancangan terlihat ada 2 buah hak akses yaitu sebagai user admin yang ditugaskan untuk memdaftarkan peserta yang mengikuti pelatihan materi algoritma pemrograman, adapun tugas sebagai admin adalah sebagai berikut :

1. Mendaftarkan akun peserta
2. Mengupload materi pembelajaran

3. Mengupload latihan soal dari sumber soal OSN

Tugas siswa adalah :

1. Mempelajari materi yang telah di upload pada aplikasi dan melakukan percobaan

2. Mencoba mengerjakan soal - soal OSN.

3. Melihat skor dari hasil latihan menjawab soal - soal

b. Tahap Implementasi

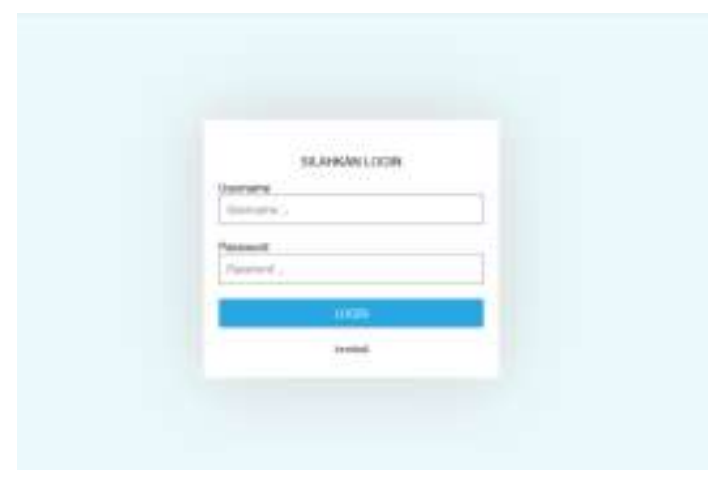

Gambar 2 Login

Gambar 2 tersebut menunjukan proses awal sebelum menjalankan aplikasi, ada 2 yang berhak login yaitu admin dan siswa

Gambar 3 Home Admin

Gambar 3 tersebut adalah tampilan home setelah melewati tahap login sebagai admin 


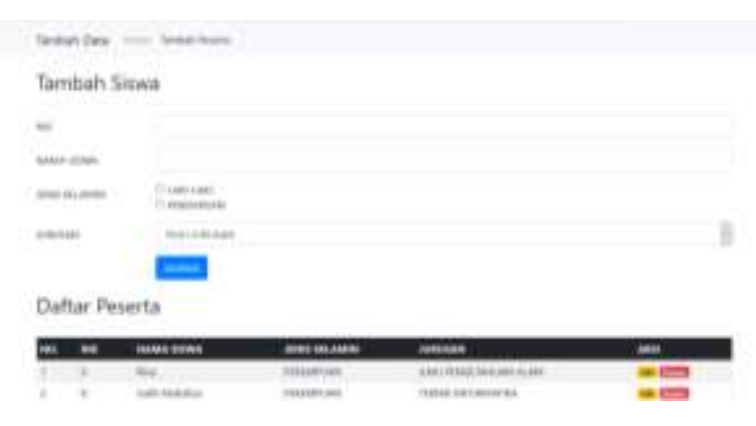

Gambar 4 Tambah Siswa

Gambar 4 tersebut adalah proses mendaftarkan siswa yang telah mengikuti seleksi pemilihan untuk menjadi calon peserta OSN, dengan tujuan bisa mengakses aplikasi tersebut dan memulai latihan pengerjaan soal-soal

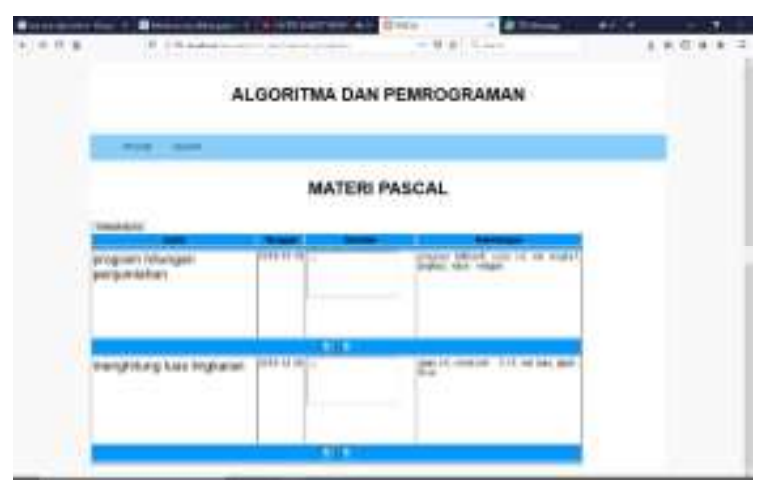

Gambar 5 Upload Materi

Gambar 5 adalah salah satu proses upload materi yang akan digunakan oleh siswa sebagai latihan

\section{c. Tahap Pengujian}

Pada tahap ini pengujian dilakukan dengan mengundang Responden sebanyak 10 Orang

Tabel 1 Pengujian Usability

$\begin{array}{lllll}\text { No Pertanyaan } & \text { TS } & \text { KS } & \text { S } & \text { SS }\end{array}$

Secara keseluruhan

1 saya puas dengan

$\begin{array}{lllll}\text { kemudahan pemakaian } & 0 & 0 & 8 & 2\end{array}$ aplikasi ini

\begin{tabular}{|c|c|c|c|c|c|}
\hline 2 & $\begin{array}{l}\text { Sangat sederhana } \\
\text { penggunaan aplikasi } \\
\text { ini }\end{array}$ & 0 & 0 & 0 & 10 \\
\hline 3 & $\begin{array}{l}\text { Saya dapat dengan } \\
\text { sempurna } \\
\text { menyelesaikan } \\
\text { pekerjaan dengan } \\
\text { aplikasi ini } \\
\end{array}$ & 0 & 0 & 2 & 8 \\
\hline 4 & $\begin{array}{l}\text { Saya dapat } \\
\text { menyelesaikan } \\
\text { pekerjaan saya dengan } \\
\text { cepat menggunakan } \\
\text { aplikasi ini }\end{array}$ & 0 & 0 & 5 & 5 \\
\hline 5 & $\begin{array}{l}\text { Saya dapat } \\
\text { menyelesaikan } \\
\text { pekerjaan saya secara } \\
\text { efisien menggunakan } \\
\text { aplikasi ini }\end{array}$ & 0 & 0 & 5 & 5 \\
\hline 6 & $\begin{array}{l}\text { Saya merasa nyaman } \\
\text { menggunakan aplikasi } \\
\text { ini }\end{array}$ & 0 & 0 & 5 & 5 \\
\hline 7 & $\begin{array}{l}\text { Sangat mudah } \\
\text { mempelajari } \\
\text { penggunaan aplikasi } \\
\text { ini }\end{array}$ & 0 & 0 & 4 & 6 \\
\hline 8 & $\begin{array}{l}\text { Pesan kesalahan yang } \\
\text { diberikan aplikasi ini } \\
\text { menjelaskan dengan } \\
\text { gamblang cara } \\
\text { mengatasinya }\end{array}$ & 0 & 2 & 5 & 3 \\
\hline 9 & $\begin{array}{l}\text { Kapanpun saya } \\
\text { membuat kesalahan, } \\
\text { saya bisa } \\
\text { memperbaikinya } \\
\text { dengan cepat dan } \\
\text { mudah }\end{array}$ & 0 & 0 & 9 & 1 \\
\hline 10 & $\begin{array}{l}\text { Informasi yang } \\
\text { disediakan aplikasi ini } \\
\text { cukup jelas }\end{array}$ & 0 & 0 & 0 & 10 \\
\hline 11 & $\begin{array}{l}\text { Sangat mudah mencari } \\
\text { informasi di aplikasi } \\
\text { ini }\end{array}$ & 0 & 0 & 7 & 3 \\
\hline 12 & $\begin{array}{l}\text { Informasi yang } \\
\text { disediakan aplikasi } \\
\text { sangat mudah } \\
\text { dipahami } \\
\end{array}$ & 0 & 0 & 0 & 10 \\
\hline 13 & $\begin{array}{l}\text { Informasi yang } \\
\text { disediakan efektif } \\
\text { membantu saya } \\
\text { mendapatkan informasi }\end{array}$ & 0 & 0 & 9 & 1 \\
\hline 14 & $\begin{array}{l}\text { Pengorganisasian } \\
\text { informasi yang } \\
\text { ditampilkan aplikasi }\end{array}$ & 0 & 0 & 10 & 0 \\
\hline
\end{tabular}


sangat jelas

\begin{tabular}{|c|c|c|c|c|c|}
\hline 15 & $\begin{array}{l}\text { Antarmuka aplikasi } \\
\text { menyenangkan }\end{array}$ & 0 & 0 & 10 & 0 \\
\hline 16 & $\begin{array}{l}\text { Saya menyukai } \\
\text { menggunakan } \\
\text { antarmuka aplikasi ini }\end{array}$ & 0 & 0 & 6 & 4 \\
\hline 17 & $\begin{array}{l}\text { Aplikasi ini memiliki } \\
\text { fungsi dan kapasitas } \\
\text { sesuai harapan saya }\end{array}$ & 0 & 2 & 7 & 1 \\
\hline 18 & $\begin{array}{l}\text { Secara keseluruhan, } \\
\text { saya puas dengan } \\
\text { aplikasi ini }\end{array}$ & 0 & 0 & 10 & 0 \\
\hline 19 & $\begin{array}{l}\text { Apakah informasi yang } \\
\text { disediakan oleh } \\
\text { aplikasi ini mudah } \\
\text { dimengerti }\end{array}$ & 0 & 0 & 10 & 0 \\
\hline 20 & $\begin{array}{l}\text { Apakah penggunakan } \\
\text { menu atau fitur } \\
\text { aplikasi menu mudah } \\
\text { digunakan }\end{array}$ & 0 & 0 & 10 & 0 \\
\hline 21 & $\begin{array}{l}\text { Apakah aplikasi ini } \\
\text { nyaman digunakan }\end{array}$ & 0 & 0 & 10 & 0 \\
\hline 22 & $\begin{array}{l}\text { Apakah aplikasi ini } \\
\text { sesuai dengan } \\
\text { kebutuhan }\end{array}$ & 0 & 0 & 9 & 1 \\
\hline 23 & $\begin{array}{l}\text { Apakah aplikasi ini } \\
\text { dapat dengan mudah } \\
\text { dipelajari }\end{array}$ & 0 & 0 & 10 & 0 \\
\hline 24 & $\begin{array}{l}\text { Apakah aplikasi ini } \\
\text { mudah dioperasikan }\end{array}$ & 0 & 0 & 10 & 0 \\
\hline 25 & $\begin{array}{l}\text { Apakah aplikasi } \\
\text { bermanfaat bagi } \\
\text { pengguna }\end{array}$ & 0 & 0 & 8 & 2 \\
\hline 26 & $\begin{array}{l}\text { Apakah tampilan menu } \\
\text { dalam aplikasi mudah } \\
\text { untuk dikenali }\end{array}$ & 0 & 0 & 10 & 0 \\
\hline 27 & $\begin{array}{l}\text { Apakah aplikasi } \\
\text { mempunyai } \\
\text { kemampuan dan fungsi } \\
\text { sesuai yang diharapkan }\end{array}$ & 0 & 0 & 10 & 0 \\
\hline & Total & 0 & 4 & 189 & 77 \\
\hline
\end{tabular}

Hasil pengujian Usability

\begin{tabular}{crrr}
\hline Tidak Setuju & 0 & $\times 100 \%$ & $0 \%$ \\
\hline Kurang Setuju & 0,01 & $\times 100 \%$ & $1 \%$ \\
\hline Setuju & 0,7 & $\times 100 \%$ & $70 \%$ \\
\hline Sangat Setuju & 0,29 & $\times 100 \%$ & $29 \%$ \\
\hline
\end{tabular}

Berdasarkan analisis deskriptif dan perhitungan maka diperoleh persentase 29\% Sangat setuju, $70 \%$ setuju, $1 \%$ kurang setuju, dan $0 \%$ untuk respon tidak setuju.

Analisis Pengujian

Tabel 2 Analisis Pengujian

\begin{tabular}{|c|c|c|c|}
\hline $\begin{array}{c}\text { Pertan } \\
\text { yaan }\end{array}$ & $\begin{array}{l}\text { Skor } \\
\text { Total }\end{array}$ & $\begin{array}{c}\text { Skor } \\
\text { Maksimum }\end{array}$ & $\%$ \\
\hline 1 & 32 & 40 & 80 \\
\hline 2 & 40 & 40 & 100 \\
\hline 3 & 38 & 40 & 95 \\
\hline 4 & 35 & 40 & 87,5 \\
\hline 5 & 35 & 40 & 87,5 \\
\hline 6 & 35 & 40 & 87,5 \\
\hline 7 & 36 & 40 & 90 \\
\hline 8 & 27 & 40 & 67,5 \\
\hline 9 & 31 & 40 & 77,5 \\
\hline 10 & 40 & 40 & 100 \\
\hline 11 & 33 & 40 & 82,5 \\
\hline 12 & 40 & 40 & 100 \\
\hline 13 & 31 & 40 & 77,5 \\
\hline 14 & 30 & 40 & 75 \\
\hline 15 & 30 & 40 & 75 \\
\hline 16 & 34 & 40 & 85 \\
\hline 17 & 25 & 40 & 62,5 \\
\hline 18 & 30 & 40 & 75 \\
\hline 19 & 30 & 40 & 75 \\
\hline 20 & 30 & 40 & 75 \\
\hline 21 & 30 & 40 & 75 \\
\hline 22 & 31 & 40 & 77,5 \\
\hline 23 & 30 & 40 & 75 \\
\hline 24 & 30 & 40 & 75 \\
\hline 25 & 32 & 40 & 80 \\
\hline 26 & 30 & 40 & 75 \\
\hline 27 & 30 & 40 & 75 \\
\hline Total & 875 & 1080 & 81 \\
\hline
\end{tabular}

Berdasarkan hasil analisa pengujian usability maka diperoleh presentase $81 \%$. Dari skor tersebut untuk aplikasi yang sederhana termasuk dalam kategori baik. 


\section{KESIMPULAN}

Kesimpulan yang didapatkan setelah melakukan implementasi dan beberapa pengujian, maka dapat dipaparkan yaitu: Tahap pengujian usability hasil analisa pengujian maka diperoleh presentase $81 \%$. Dari skor tersebut untuk aplikasi yang sederhana termasuk dalam kategori baik.

\section{REFERENSI}

1] A. Kadir, "Pengenalan Sistem Informasi," Am. Enterp. Inst. Public Policy Res., 2014.

2] FN. Jovan, "Panduan Praktis Membuat WEB dengan PHP utk Pemula," MediaKita., 2014.

3] Mahalisa, G. (2018). PERANCANGAN SISTEM INFORMASI KAMPUS (SIK) BERBASIS WEBSITE STUDI KASUS KAMPUS UNISKA. SEMINASTIKA UNIVERSITAS MULIA BALIKPAPAN, 1(001), 101-103.

4] Mahalisa, G., \& Syafarina, G. A. (2018). ANALISIS PERANCANGAN ESCHEDULE PERKULIAHAN. Technologia: Jurnal Ilmiah, 9(3), 185187.
5] Y. Utama, "Sistem Informasi Berbasis Web Jurusan Sistem Informasi Fakultas Ilmu Komputer Universitas Sriwijaya," $J$. Sist. Inf., 2011.

6] A. Prayitno and Y. Safitri, "Pemanfaatan Sistem Informasi Perpustakaan Digital Berbasis Website Untuk Para Penulis," Softw. Eng., 2015.

7] D. Puspitasari, "Sistem Informasi Perpustakaan Sekolah Berbasis Web," J. Pilar Nusa Mandiri, 2016.

8] A. P. M. A. Arif, Nur Saiful; Wanda, "Aplikasi Administrasi Perpustakaan Berbasis Web Smk Swasta Brigjend Katamso Medan," J. Ilm. Saintikom, 2013

9] Kasiman, P. (2009). Aplikasi Web dengan $P H P$ dan MySQL. Yogyakarta: ANDI.

10] Martin, J. (1990). Information Enginering Book II Planning and Analysis 2nd Edition. New Jersey: Prentice-Hall.

11] Peranginangin, K. (2006). Aplikasi WEB dengan PHP dan MySQL. Yogyakarta: ANDI. 